\title{
Analysis of Economic Efficiency in Some Irish Farms Using the DEA Approach
}

\author{
Nicola Galluzzo* \\ Via Salaria per L'Aquila 76 Scala A Rieti Italy
}

\begin{tabular}{l} 
A R T I C L E I N F O \\
Research Article \\
Received 30 August 2017 \\
Accepted 16 January 2018 \\
\hline
\end{tabular}

Keywords:

FADN

Common agricultural policy

Rural development

DEA

Economic efficiency

*Corresponding Author: \begin{abstract}
A B S T R A C T
Irish farms are predominately and highly specialized in crops as cereals, protein crops and in dairy productions. The aim of this research was to estimate the economic efficiency in Irish farms part of the Farm Accountancy Data Network (FADN) dataset stratified in function of their own typology of productive specialization since 2004 to 2015 by a quantitative approach such as the Data Envelopment Analysis (DEA). Positive has been the role of inputs as financial subsidies allocated by the Common Agricultural Policy, the first and second pillar, in increasing the economic efficiency of Irish farms. Field crops farms have not had the best results in terms of the economic efficiency even if over the time, in particular during the economic crises 2008-2009, findings have not been stable with significant fluctuations and a sharply decrease of efficiency as a consequence of economic turbulences. Focusing the attention on the research outcomes in all years of investigation comparing also the different typology of farming, mixed farms and farms with animals, such as specialist cattle, sheep, goats and other grazing livestock, have had the highest levels of economic efficiency equal to $100 \%$; by contrast Irish dairy farms have had the modest levels of economic efficiency close to $77 \%$.
\end{abstract}

E-mail: asgear@libero.it

DOI: https://doi.org/10.24925/turjaf.v6i2.156-162.1492

\section{Introduction}

The dimension of farms in terms of land capital is one of the most pivotal variable and also a limiting constraint in stimulating and improving the level of investments and efficiency in farms. Farms size, type of ownership, endowment in social capital, age of farmers, typology of management and ageing of people living in the countryside have been assessed as pivotal variables able to impact on the technical, economic and allocative efficiency in farms located in lots of different European countries (Galluzzo, 2013; Latruffe and Nauges, 2014; Latruffe et al., 2004; Latruffe, 2010; Latruffe et al., 2005; Bojnec and Latruffe, 2008; Davidova and Latruffe, 2007; Latruffe et al., 2012). By contrast, many authors have investigated in depth the predominant role of different factors such as financial subsidies allocated by the Common Agricultural Policy, crop specialization and farm size towards the efficiency in farms using as source of data the Farm Accountancy Data Network or in sample of European farms as well (Galluzzo, 2016; 2017; Camelia and Vasile, 2016; Bojnec and Latruffe, 2008; Davidova and Latruffe, 2007; Latruffe et al., 2012; Marongiu et al., 2010). Since 1965, aimed at assessing the impact of the Common Agricultural Policy towards European farmers belonging to the European Countries, the European Economic Community by the Council Regulation number 79 has set up an annual survey on a sample of farmers called Farm Accountancy Data Network or FADN (EC, 2014). Addressing the attention to Ireland, in order to investigate if there is a nexus between farm's productive specialization (type of farming) and efficiency, several quantitative studies have assessed in some farms specialized in milk production the trend of efficiency over the time comparing the efficiency both within systems of production and also among the type of farms such as farmers with sheep (Newman and Matthews, 2006; Newman and Matthews, 2007). However, these latter scholars have argued as the level of specialization of farms in dairy production implied the highest level of efficiency.

The purpose of this research was to assess by a quantitative approach the economic efficiency in Irish farms belonging to the Farm Accountancy Data Network (FADN) since 2004 to 2015. Irish farms have been stratified in function of their own predominant type of farming, such as field crops, horticulture, wine, other permanent crops, milk, other grazing livestock, granivores (pigs and poultry), mixed, following the general guidance and specifications published by the European Union in the 
Regulation 1242/2008. Due to the highest level of agrarian specialization in some crops and breeding, in the Irish FADN dataset are represented only 4 type of farms as milk farms or rather specialist dairying farms, field crop enterprises (cereals, oilseeds and protein crops), mixed farms with various crops, field crops and livestock combined and the last type of farms made by other grazing livestock enterprises (specialist cattle in rearing and fattening, cattle specialised dairying, rearing and fattening combined and sheep, goats and other grazing livestock). Furthermore, in each type of farms has been estimated the evolution of the economic efficiency during the time of study.

Table 1 Main inputs and output in the FADN dataset used in the analysis of efficiency estimated by the DEA model

\begin{tabular}{|c|c|c|}
\hline Input variable & Unit & Description \\
\hline Labour input & $\mathrm{h}$ & Total labour input in hours \\
\hline Usable agricultural areas & ha & Total agricultural surface \\
\hline Specific costs & $€$ & Cost for specific inputs, for forestry and livestock specific inputs \\
\hline Seed costs & $€$ & Costs with a nexus to agricultural crops \\
\hline Fertilizers costs & $€$ & Costs for purchasing fertilizers and other soil improvers \\
\hline Crop protection costs & $€$ & Costs of plant protection products, traps etc. \\
\hline Other costs & $€$ & $\begin{array}{l}\text { Different costs correlated to the soil, crops, purchase of crop } \\
\text { products }\end{array}$ \\
\hline Feed animal cost & $€$ & Cost for concentrated feeding stuffs and others factors \\
\hline Overhead costs & $€$ & Total supply costs linked to production activity \\
\hline Taxes & $€$ & Farm taxes and other dues linked also to the land and buildings \\
\hline $\begin{array}{l}\text { Environmental subsidies allocated by the } \\
\text { CAP }\end{array}$ & $€$ & $\begin{array}{l}\text { Payments allocated towards an environmental protection such as } \\
\text { some of them proposed by Regulation } 1782 / 2003\end{array}$ \\
\hline LFA payments & $€$ & Financial supports towards stayed behind rural areas \\
\hline $\begin{array}{l}\text { Subsidies allocated by the Second Pillar of } \\
\text { the CAP }\end{array}$ & $€$ & $\begin{array}{l}\text { Financial subsidies allocated by the National Rural Development } \\
\text { Plan }\end{array}$ \\
\hline Decoupled payments & $€$ & Single farm payment and single area payments scheme \\
\hline Output variable & Unit & Description \\
\hline Farm net income & $€$ & Remuneration of work, land, capital and profit of farmer \\
\hline Total output & $€$ & $\begin{array}{l}\text { Total output by crop, crop products, livestock and other output in } \\
\text { farm }\end{array}$ \\
\hline
\end{tabular}

Source: http://ec.europa.eu/agriculture/rica/database/database_en.cfm

\section{Methodology}

The assessment of efficiency can be made by a parametric method which needs of a specific function of production described in literature and some well-defined variables (Farrell, 1957; Charnes et al., 1978; Battese, 1992; Coelli, 1996) This latter approach is called parametric method. In this paper, it has been harsh to use the parametric approach due to lots of inputs put in the model and also to the shortage of a specific quantitative model correlated to the factors of production. In these paper, it has used a non-parametric methodology or DEA (Data Envelopment Analysis) with the purpose to define a hypothetical function of production tightly linked to the set of investigated input variables published in the FADN Irish dataset and output variables such as farm net income and total output (Table 1). In all different groups of farms stratified in function of their productive specialization belonging to the Irish FADN dataset it has used the same set of input and output as reported in Table 1 with the purpose to make easily comparable the efficiency in all different categories of farms estimated in the DEA model.

The non-parametric linear model estimated by the Data Envelopment Analysis has been described for the first time in 1978 (Charnes et al., 1978). The positive advantage of the DEA is due to an opportunity to arrange a hypothetical function of production made by a different combination of input and output hence, the distance from the frontier of this function is the index of technical inefficiency (Latruffe, 2010; Galluzzo, 2013; Charnes et al., 1978; Battese, 1992; Coelli, 1996; Farrell, 1957). In fact, along this function there are all the possible combinations of inputs or output able to minimize costs or maximize the income. Roughly speaking, fluctuations in the model from the frontier of the function of production are inefficient and the technical efficiency is described as a set of opportunities for entrepreneurs in maximizing the output minimizing in the same time inputs or vice versa (Bojnec and Latruffe, 2008). In this research, the economic efficiency has been estimated by a nonparametric model applied to a variable return to scale or VRS in an input oriented model (Farrell, 1957; Battese, 1992; Coelli, 1996) using the DEAP 2.1 software in Irish farms part of the FADN dataset.

Coelli in 1998 argued as one of the best method in estimating the efficiency by the DEA approach in a Decision Making Unit (DMU) or in this case a single Irish farm is a simply ratio between all output on all input written as $u^{\prime} y_{i} / v^{\prime} x_{i}$ where $u^{\prime}$ and $v^{\prime}$ are two vectors of input and output weights and the linear transformation of this general theoretical framework can be expressed as this expression whose bottleneck is to have got infinite solutions (Coelli, 1998):

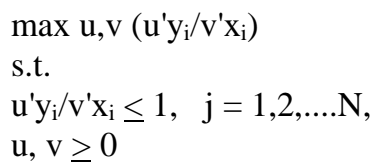


According to this above-mentioned author the best solution is to define a constraint so that $\mathrm{v}^{\prime} \mathrm{x}_{\mathrm{i}}$ is equal to 1 or $100 \%$ and in formula it can be written as (Coelli, 1998; Battese, 1992):

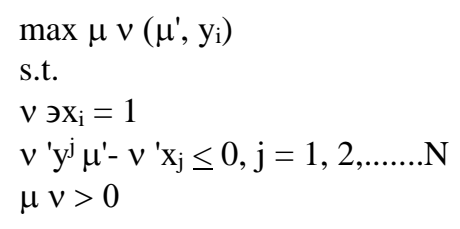

In this case $\mu$ and $v$ are a transformation of $u$ and $v$ using this transformation in a duality process the model where $\theta$ and $\lambda$ is a Nx1 vector of constant hence, the function to minimize is:

$$
\begin{aligned}
& \min \theta, \lambda \theta \\
& \text { s.t. } \\
& -\mathrm{y}_{\mathrm{i}}+\mathrm{Y} \lambda \geq 0 \\
& \theta \mathrm{x}_{\mathrm{i}}-\mathrm{X} \lambda>0 \\
& \lambda>0
\end{aligned}
$$

If $\theta$ for each farm is close to 1 this implies as the solution are along the frontier of the hypothetical function of production.

In term of productivity if there are two firms or Decision Making Units (DMUs) such as A and B able to produce two levels of output such as $y_{a}$ or $y_{b}$ using a specific quantity of input as $\mathrm{x}_{\mathrm{a}}$ and $\mathrm{x}_{\mathrm{b}}$ the productivity is a ratio between produced output on used input $y a / x_{a}$ and $\mathrm{y}_{\mathrm{b}} / \mathrm{x}_{\mathrm{b}}$. In general, if there is an efficient solution the value is equal to 1 or $100 \%$ which implies as for producing an unit of output it has used the same quantity of input.

The aim of a non-parametric input oriented model, used in this research is to minimize in a multiple-output model, made up by the variables farm net income and total output, the multiple-input (Table 1) in each farms part of the Irish FADN database that is a ratio of efficiency it is possible to assess numerous possible solutions hence, the value of efficiency is in range between 0 and 1 (Bhagavath 2009; Galluzzo, 2013; 2016). If $h$ or rather the value of efficiency is close to 1 or $100 \%$ each farm or Decision Making Unit (DMU) is more efficient compared to other $\mathrm{DMUh}_{\mathrm{n}}$, but whether $\mathrm{h}$ is not equal to 1 or $100 \%$ there are lots of units more efficient than this unique and inefficient unit $\left(\mathrm{DMUh}_{1}\right)$ then, every units is tightly linked to the level of input and output making each unit efficient (Bhagavath, 2009).

\section{Results and discussion}

The main findings in the Irish FADN dataset during the time of study 2004-2015 have pointed out an economic dimension of farms estimated in European Size Unit which is equal to 1,200 euro quite significant with an average value close to 63.11 even if the range of fluctuation is between 18 and 135 (Table 2). The best economic performances in Irish farms are tightly correlated to the endowment of land capital in terms of usable agricultural surface which is above 55 hectares even if not so common is for Irish farmers renting land.

In general, the ratio between produced output per used input is close to 1 and the farm net income is one third of the total output produced in farms with significant fluctuations between Irish farms due to the farm's size and also to the productive specialization. Outcomes have underlined a positive and intense effect on the level of farm income of payments allocated by the second pillar of the CAP or rather by measures aimed at stimulating the rural diversification, pluriactivity and multifunctionality in the countryside by the National Rural Development Plan and also in improving the standard living conditions in rural territories. However, decoupled financial supports allocated by the first pillar of the Common Agricultural Policy are in average value five times higher than payments disbursed by the second pillar.

Table 2 Descriptive statistics in input and output variables

\begin{tabular}{l|rrrr}
\hline \multicolumn{1}{c|}{ Input } & \multicolumn{1}{c}{ Mean } & Std. Deviation & \multicolumn{1}{c}{ Min } & Max \\
\hline Labour input $(€)$ & $2,444.99$ & 73.54 & $2,343.11$ & $2,556.85$ \\
Usable agricultural areas (ha) & 55.54 & 9.40 & 38.38 & 76.26 \\
Specific costs $(€)$ & $23,340.80$ & $7,672.49$ & $14,162.00$ & $35,025.00$ \\
Seed costs $(€)$ & 528.75 & 98.95 & 407.00 & 760.00 \\
Fertilizers costs $(€)$ & $4,879.83$ & $1,357.60$ & $3,306.00$ & $7,240.00$ \\
Crop protection costs $(€)$ & 762.83 & 165.95 & 566.00 & 998.00 \\
Other costs $(€)$ & 403.33 & 76.64 & 290.000 & 506.00 \\
Feed animal cost $(€)$ & $12,402.30$ & $4,773.13$ & $6,253.00$ & $20,699.00$ \\
Overhead costs $(€)$ & $12,408.40$ & $2,531.63$ & $8,750.00$ & $15,838.00$ \\
Taxes $(€)$ & 175.583 & 49.59 & 122.00 & 253.00 \\
Environmental subsidies allocated by the CAP $(€)$ & $2,788.50$ & 779.71 & 871,00 & $3,601.00$ \\
LFA payments $(€)$ & $2,091.83$ & 167.97 & $1,916.00$ & $2,388.00$ \\
Subsidies allocated by the Second Pillar of the CAP $(€)$ & $4,258.62$ & $1,394.80$ & 690.00 & $6,984.00$ \\
Decoupled payments $(€)$ & $12,486.30$ & $4,006.22$ & 0,00 & $15,231.00$ \\
\hline Output & Mean & Std. Deviation & Min & Max \\
Farm net income $(€)$ & $31,203.63$ & $16,831.29$ & 9,628 & $79,158.00$ \\
\hline Total output $(€)$ & $82,428.73$ & $46,559.26$ & 19,554 & $190,593.00$ \\
\hline So & & &
\end{tabular}

Source: author's elaboration on FADN data on http://ec.europa.eu/agriculture/rica/database/database_en.cfm 
Table 3 Main descriptive statistics of some variables in farms belonging to FADN dataset

\begin{tabular}{l|rrrr}
\hline \multicolumn{1}{c|}{ Variable } & Mean & Std. Deviation & \multicolumn{1}{c}{ Min } & Max \\
\hline Economic dimension (ESU) & 63.11 & 33.52 & 18.40 & 135.50 \\
Usable agricultural area (Ha) & 55.54 & 9.40 & 38.38 & 76.26 \\
Rented usable agricultural area (Ha) & 12.73 & 5.36 & 5.63 & 28.30 \\
Total output $(€)$ & $82,428.73$ & $46,559.26$ & 19,554 & 190,593 \\
Total output/total input & 1.05 & 0.18 & 0.72 & 1.39 \\
Farm net income $(€)$ & $31,203.63$ & $16,831.29$ & 9,628 & 79,158 \\
Subsidies II pillar CAP $(€)$ & $4,258.62$ & $1,394.80$ & 690.00 & 6,984 \\
CAP payments $(€)$ & $23,077.88$ & $4,383.08$ & 11,933 & 30,238 \\
\hline
\end{tabular}

Source: author's elaboration on data FADN published on http://ec.europa.eu/agriculture/rica/database/database_en.cfm

Table 4 Main findings in the economic efficiency and metafrontier efficiency estimated in Irish farms part of Farm Accountancy Data Network dataset

\begin{tabular}{|c|c|c|c|c|}
\hline \multicolumn{5}{|c|}{ Economic efficiency for each typology of farming } \\
\hline $\begin{array}{c}\text { Type of } \\
\text { farms }\end{array}$ & $\begin{array}{l}\text { Constant Return to } \\
\text { Scale }\end{array}$ & $\begin{array}{l}\text { Variable Return to } \\
\text { Scale }\end{array}$ & $\begin{array}{c}\text { Scale } \\
\text { efficiency }\end{array}$ & $\begin{array}{c}\text { Type of return to } \\
\text { scale }\end{array}$ \\
\hline Field crops & 100.00 & 100.00 & 100.00 & - \\
\hline Milk & 76.60 & 100.00 & 76.60 & irs \\
\hline Other grazing & 100.00 & 100.00 & 100.00 & - \\
\hline Mixed & 100.00 & 100.00 & 100.00 & - \\
\hline Mean & 94.10 & 100.00 & 94.10 & \\
\hline \multicolumn{5}{|c|}{ Metafrontier economic efficiency for each typology of farming } \\
\hline $\begin{array}{c}\text { Type of } \\
\text { farms }\end{array}$ & $\begin{array}{l}\text { Constant Return to } \\
\text { Scale }\end{array}$ & $\begin{array}{l}\text { Variable Return to } \\
\text { Scale }\end{array}$ & $\begin{array}{c}\text { Scale } \\
\text { efficiency }\end{array}$ & $\begin{array}{l}\text { Type of return to } \\
\text { scale }\end{array}$ \\
\hline Field crops & 100.00 & 100.00 & 100.00 & - \\
\hline Milk & 96.20 & 100.00 & 96.20 & irs \\
\hline Other grazing & 100.00 & 100.00 & 100.00 & - \\
\hline Mixed & 100.00 & 100.00 & 100.00 & - \\
\hline Mean & 99.00 & 100.00 & 99.00 & \\
\hline
\end{tabular}

Source: author's elaboration on FADN data published on the website http://ec.europa.eu/agriculture/rica/database/database_en.cfm,

irs: stands for increasing return to scale

In Table 3 are described the main economic features of Irish farm belonging to the FADN such as the economic dimension (ESU) which expresses the standard gross margin of farm equal, according to the Eurostat, to a threshold of 1,200 euro hence, throughout this variable it is possible to assess the economic size of agricultural enterprises. The dimension of land capital in hectares of usable agricultural area and rented agricultural areas is pivotal in estimating the endowment of land which correlates directly to the level of output and income produced by farmers.

The produced total output in euro is a partial index of the technical efficiency of farms because it describes the quantity of total output produced by farm using a defined quantity of input and higher is the amount of total output more wide and efficient is the farm. The net income is a variable of output able to outline the return of direct, indirect money and non monetary goods to farmers hence, it describes if all capital and goods invested in farms are adequately remunerated. The financial subsidies allocated by the first and second pillar of the CAP are fundamental for farmers in increasing the level of investments and in stimulating new activities in farms or compensating partially some productions with a low impact to the environmental as organic crops. Addressing the attention on the financial aids disbursed by the first pillar of the Common Agricultural Policy they are predominately made up by decoupled payments.
Focusing the attention on the different items of financial subsidies and payments allocated by the Common Agricultural Policy, findings have pointed out as single farms payments and decoupled financial supports disbursed by the first pillar of the CAP have had in average a significant incidence to farmers (Table 3 ). Actions and measures in supporting the rural development, the environment protection and direct financial supports towards disadvantaged rural areas are quantitative poorer compared to other decoupled payments and aids allocated by the European Union towards farmers throughout the first and second pillar of the Common Agricultural Policy.

Comparing the 4 types of farms, findings of economic efficiency have pointed out the best performances in filed crops, other grazing farms and mixed farms (Table 4); the worst result has been found in some farms specialized in dairy production which have had an optimal level of economic efficiency considering the variable return to scale method. Irish dairy farms have also had the highest level of distance from the metafrontier economic efficiency function compared to the other groups of agricultural enterprises.

The further stage of the efficiency analysis has estimated in Irish farms belonging to the FADN dataset the trend of the economic efficiency over the time aimed at investigating in which year it has been possible to assess the best results of economic efficiency. 
Table 5 Main results in the economic efficiency analysis over the time in the field crop farms.

\begin{tabular}{|c|c|c|c|c|}
\hline Year & $\begin{array}{c}\text { Constant Return to } \\
\text { Scale }\end{array}$ & $\begin{array}{c}\text { Variable Return to } \\
\text { Scale }\end{array}$ & $\begin{array}{c}\text { Scale } \\
\text { efficiency }\end{array}$ & $\begin{array}{c}\text { Type of return to } \\
\text { scale }\end{array}$ \\
\hline 2004 & 100.00 & 100.00 & 100.00 & - \\
\hline 2005 & 76.60 & 100.00 & 100.00 & irs \\
\hline 2006 & 100.00 & 100.00 & 100.00 & - \\
\hline 2007 & 100.00 & 100.00 & 100.00 & - \\
\hline 2008 & 57.20 & 100.00 & 57.20 & irs \\
\hline 2009 & 63.90 & 100.00 & 63.90 & irs \\
\hline 2010 & 100.00 & 100.00 & 100.00 & - \\
\hline 2011 & 100.00 & 100.00 & 100.00 & - \\
\hline 2012 & 100.00 & 100.00 & 100.00 & - \\
\hline 2013 & 84.60 & 95.00 & 90.90 & irs \\
\hline 2014 & 100.00 & 100.00 & 100.00 & - \\
\hline 2015 & 100.00 & 100.00 & 100.00 & - \\
\hline Mean & 90.30 & 100.00 & 100.0 & \\
\hline
\end{tabular}

Source: author's elaboration on FADN data published on the website http://ec.europa.eu/agriculture/rica/database/database_en.cfm;

irs: stands for increasing return to scale

Table 6 Main findings in the analysis of economic efficiency in farms specialized in dairy production.

\begin{tabular}{l|cccc}
\hline Year & Constant Return to & Variable Return to & Scale & Type of return to \\
Scale & efficiency & - \\
\hline 2004 & 100.00 & Scale & 100.00 & - \\
2005 & 100.00 & 100.00 & 100.00 & irs \\
2006 & 90.00 & 100.00 & 90.00 & - \\
2007 & 100.00 & 100.00 & 100.00 & irs \\
2008 & 79.91 & 100.00 & 80.70 & irs \\
2009 & 63.10 & 97.90 & 66.10 & irs \\
2010 & 85.80 & 95.40 & 88.50 & - \\
2011 & 100.00 & 97.00 & 100.00 & irs \\
2012 & 72.00 & 100.00 & 72.60 & irs \\
2013 & 94.30 & 99.20 & 94.30 & - \\
2014 & 100.00 & 100.00 & 100.00 & - \\
2015 & 100.00 & 100.00 & 100.00 & - \\
\hline Mean & 90.40 & 100.00 & 91.00 & \\
\hline
\end{tabular}

Source: author's elaboration on FADN data published on the website http://ec.europa.eu/agriculture/rica/database/database_en.cfm; irs: stands for increasing return to scale

Table 7 Main findings in the economic efficiency in the cluster other grazing Irish farms.

\begin{tabular}{c|cccc}
\hline Year & $\begin{array}{c}\text { Constant Return to } \\
\text { Scale }\end{array}$ & $\begin{array}{c}\text { Variable Return to } \\
\text { Scale }\end{array}$ & $\begin{array}{c}\text { Scale } \\
\text { efficiency }\end{array}$ & $\begin{array}{c}\text { Type of return to } \\
\text { scale }\end{array}$ \\
\hline 2004 & 100.00 & 100.00 & 100.00 & - \\
2005 & 100.00 & 100.00 & 100.00 & - \\
2006 & 99.40 & 100.00 & 100.00 & irs \\
2007 & 100.00 & 100.00 & 100.00 & - \\
2008 & 97.20 & 99.30 & 98.00 & irs \\
2009 & 100.00 & 100.00 & 100.00 & irs \\
2010 & 73.90 & 100.00 & 73.90 & - \\
2011 & 100.00 & 100.00 & 100.00 & drs \\
2012 & 94.10 & 100.00 & 94.10 & irs \\
2013 & 77.60 & 98.10 & 79.00 & irs \\
2014 & 89.00 & 100.00 & 89.00 & - \\
2015 & 100.00 & 100.00 & 100.00 & 94.50 \\
Mean & 94.30 & 99.80 & & \\
\hline
\end{tabular}

Source: author's elaboration on FADN data published on the website http://ec.europa.eu/agriculture/rica/database/database_en.cfm; irs: stands for increasing return to scale; drs stands for decreasing return to scale

The analysis of economic efficiency in the typology of farms characterised by field crops has pointed out over the time of investigation some values of economic efficiency both in constant return to scale (CRTS) and also in variable return to scale (VRTS) under the optimal threshold equal to $100 \%$ (Table 5). In 2005, 2008, 2009 and in 2013 there has been an increasing return to scale; outcomes in all remaining years have underlined values of economic efficiency close to the optimal value of economic efficiency with a value close to the threshold of $100 \%$. 
Irish farms specialized in dairy productions have underlined an average value of economic efficiency lower than $90 \%$ considering the constant return to scale by contrast it has been very close to the threshold of $100 \%$ in the variable return to scale approach (Table 6). In general, six years out of 12 have pointed out an increasing return to scale and in 2009 only it has been found the worst result of economic efficiency in farms specialized in milk production.

Other enterprises belonging to the Irish FADN dataset classified in the type grazing farms have had an average amount of economic efficiency under the threshold of $100 \%$ both in constant and also in variable return to scale (Table 7). Findings have pointed out in 2012 a decreasing return to scale and in five years out of 12 , respectively 2006, 2008, 2010, 2013 and in 2014 only an increasing return to scale has assessed.

The mixed farms have pointed out the lower level of efficiency both in terms of constant return to scale and also in terms of variable return to scale with an average value of economic efficiency very close to the optimal level considering only the variable return to scale approach (Table 8). In five years out of twelve outcomes of mixed Irish farms belonging to the Farm Accountancy Data Network dataset have pointed out an increasing return to scale.

Summing up, in the type of farms made by other grazing agrarian enterprises findings have pointed out the highest average levels of economic efficiency in constant and in variable return to scale over the time of investigation; instead, the mixed farms and enterprises specialized in field crops have had the lowest level of efficiency. Mixed farms have had the poorest level of economic efficiency due to a not efficient use of inputs over the time corroborating the theoretical hypothesis, argued by lots of authors as reported in the introduction section, according to which the level of specialization of farms influences the level of efficiency.

Table 8 Economic efficiency in type of farms classified as mixed Irish farms.

\begin{tabular}{l|cccc}
\hline Year & $\begin{array}{c}\text { Constant Return to } \\
\text { Scale }\end{array}$ & $\begin{array}{c}\text { Variable Return to } \\
\text { Scale }\end{array}$ & $\begin{array}{c}\text { Scale } \\
\text { efficiency }\end{array}$ & $\begin{array}{c}\text { Type of return to } \\
\text { scale }\end{array}$ \\
\hline 2004 & 100.00 & 100.00 & 100.00 & - \\
2005 & 100.00 & 100.00 & 100.00 & - \\
2006 & 100.00 & 100.00 & 100.00 & - \\
2007 & 100.00 & 100.00 & 100.00 & - \\
2008 & 55.20 & 100.00 & 55.20 & irs \\
2009 & 64.50 & 100.00 & 64.50 & irs \\
2010 & 100.00 & 100.00 & 100.00 & - \\
2011 & 97.70 & 100.00 & irs \\
2012 & 100.00 & 100.00 & - & - \\
2013 & 79.60 & 100.00 & 700.00 & irs \\
2014 & 93.90 & 98.80 & 95.60 & irs \\
2015 & 100.00 & 100.00 & 100.00 & - \\
Mean & 90.90 & 99.90 & 91.00 & \\
\hline
\end{tabular}

Source: author's elaboration on FADN data published on the website website http://ec.europa.eu/agriculture/rica/database/database_en.cfm; irs: stands for increasing return to scale

\section{Conclusions}

In this research, findings have corroborated the direct impact of specialized farms in increasing the efficiency in Irish farms even if a mixed combination of crops and animals do impact on a worsening of economic efficiency. Findings in this research have strengthened the fundamental role of land capital as one of the most important input correlated directly to an increase of economic efficiency in particular in dairy and in other grazing farms. Summing up, during the economic recession in 2008-2010 all Irish farms have suffered a price increase in some inputs such as cost of feedings, particularly in dairy farms, and specific costs for crops; hence, in order to get better the economic efficiency is pivotal to reduce some inputs in terms of cost such as cost of feedings, specific costs for crop (fertilizers and other pesticides) and increasing the level of decoupled payments allocated by the Common Agricultural Policy. Furthermore, the impact of Common Agricultural Policy payments allocated by the second pillar has been positive in expanding the level of farmer's income and in the same it has had a direct impact in increasing the economic efficiency. Efforts in a next process of re-programming of the CAP towards Irish farms should be address to dairy specialized farms which have pointed out the lowest values of economic and efficiency and this is particular important afterward the phasing out of the quota system in relation to the European dairy market.

For the future, it is important with the purpose to stimulate the rural diversification in Irish countryside and in reducing the emigration of workforce from the rural space, which is a typical common issue and feature of all European nations, to increase economic resources and financial subsidies tailored in implementing the rural diversification and in supporting the less favoured rural areas as corroborated in other European states. However, these latter kinds of financial supports are not typical and adequate to the Irish agrarian fabric hence, it is fundamental to implement the amount of other financial measures disbursed by the CAP such as decoupled payments.

\section{References}

Battese GE. 1992. Frontier production functions and technical efficiency: a survey of empirical applications in agricultural economics, Agricultural Economics 7(3-4): 185-208. DOI: dx.doi.org/10.1016/0169-5150(92)90049-5. 
Bhagavath V. 2009. Technical Efficiency Measurement by Data Envelopment Analysis: An Application in Transportation, Alliance Journal of Business Research 2(1): 60-72. Available from: www.ajbr.org/ . [Accessed 15 June 2017].

Bojnec S, Latruffe L. 2008. Measures of farm business efficiency. Industrial Management \& Data Systems, 108(2): 258-270. DOI: dx.doi.org/10.1108/02635570810847617.

Camelia B, Vasile B. 2016. The economic farm size and sustainable value disparities between Romania and the EU States. Annals of Constantin Brancusi University of Targu-Jiu.Economy Series, 1: $50-57$.

Camelia B, Vasile B. 2016. The economic farm size and sustainable value disparities between Romania and the EU States. AnnalsEconomy Series, 1: 50-57.

Charnes A, Cooper WW, Rhodes E. 1978. Measuring the Efficiency of Decision Making Units. European Journal of Operational Research, 2(6): 429-444. DOI: dx.doi.org/10.1016/03772217(79)90229-7

Coelli T. 1996. Recent developments in frontier modelling and efficiency measurement. Australian Journal of agricultural economics, 39(3): 219-245.

Coelli T. 1998. A multi-stage methodology for the solution of orientated DEA models. Operations Research Letters, 23(3-5): 143-149. DOI: dx.doi.org/10.1111/j.1467-8489.1995.tb00552.x.

Davidova S, Latruffe L. 2007. Relationships between technical efficiency and financial management for Czech Republic farms. Journal of Agricultural Economics 58(2): 269-288. DOI: dx.doi.org/10.1111/j.1477-9552.2007.00109.x.

EC. 2014. European Commission Agriculture and Rural Development, Concept of FADN. Available from: www.ec.europa.eu/agriculture/rica/concept_en.cfm. [Accessed 15 May 2017].

Farrell MJ. 1957. The measurement of productive efficiency. Journal of Royal Statistical Society, 120(3): 253-281.DOI: dx.doi.org/10.2307/2343100.

Galluzzo N. 2013. Farm dimension and efficiency in Italian agriculture: a quantitative approach. American Journal of Rural Development 1(2): 26-32.

Galluzzo N. 2016. An analysis of the efficiency in a sample of small Italian farms part of the FADN dataset. Agric. Econ.-Czech, 62: 62-70. DOI: dx.doi.org/10.17221/37/2015-AGRICECON.
Galluzzo N. 2017. Economic and technical efficiency in less favoured Slovenian areas. Agricultural Science, 9(21): 83-90.

Latruffe L. 2010. Competitiveness, productivity and efficiency in the agricultural and agri-food sectors. Available from: https://www.researchgate.net. [Accessed 15 May 2017].

Latruffe L, Nauges C. 2014. Technical efficiency and conversion to organic farming: the case of France. European Review of Agricultural Economics, 41(2): 227-253. DOI: dx.doi.org/10.1093/erae/jbt024.

Latruffe L, Balcombe K, Davidova S, Zawalinska K. 2004. Determinants of technical efficiency of crop and livestock farms in Poland. Applied economics, 36(12): 1255-1263. DOI: dx.doi.org/10.1080/0003684042000176793.

Latruffe L, Balcombe K, Davidova S, Zawalinska K. 2005. Technical and scale efficiency of crop and livestock farms in Poland: does specialization matter?. Agricultural economics, 32(3): 281-296. DOI: dx.doi.org/10.1111/j.15740862.2005.00322.x.

Latruffe L, Fogarasi J, Desjeux Y. 2012. Efficiency, productivity and technology comparison for farms in Central and Western Europe: The case of field crop and dairy farming in Hungary and France. Economic Systems, 36(2): 264-278. DOI: dx.doi.org/10.1016/j.ecosys.2011.07.002.

Marongiu S, Cesaro L, Latruffe L, Desjeux Y. 2010. L'Efficienza tecnica delle aziende agricole di montagna: analisi dei dati RICA e confronto fra montagna Italiana e Francese. In: Proceedings of 31 Annual scientific conference AISRe. Aosta 20-22 September 2010. Available from: https://aisre.it/images/old_papers/Marongiu.pdf. [Accessed 15 May 2017].

Newman C, Matthews A. 2006. The productivity performance of Irish dairy farms 1984-2000: a multiple output distance function approach. Journal of Productivity Analysis, 26(2), 191-205. DOI: dx.doi.org/10.1007/s11123-006-0013-7.

Newman C, Matthews A. 2007. Evaluating the productivity performance of agricultural enterprises in Ireland using a multiple output distance function approach. Journal of Agricultural Economics, 58(1): 128-151.DOI: dx.doi.org/10.1111/j.1477-9552.2007.00084.x. 